\title{
Database Information System for Analysis of Designing Data on Sales of Drinking Water PT Kalimantan Jaya Utama Nusantara
}

\author{
Adetya Bayu Nasution* Juhriansah Dalle \\ Magister of Business Administration Program, Lambung Mangkurat University, Indonesia
}

\begin{abstract}
PT Kalimantan Jaya Utama Nusantara is the company who produces drinking water in a gallon in the District of Tabalong, South Kalimantan. Compliance number PT is Kalimantan Jaya Utama Nusantara NATIONAL SKT No. 1069/30 / DJB / 2015. Based on an interview with PT Kalimantan Jaya Utama Nusantara obtained information that the sales in 2016, $2017 \& 2018$ has declined $1.08 \%$ in the past three years. It is because the company can develop their business and lack of information. See the deficiencies, analysis and design of information systems of sales on PT Kalimantan Jaya Utama Nusantara. It is expected to be able to produce a reference for developers of information systems, see sales opportunity, evaluate and take the right decisions for companies.
\end{abstract}

Keywords: Sales, Information System, System Information of Sales.

DOI: $10.7176 /$ JIEA/8-1-06

\section{Introduction}

PT Kalimantan Jaya Utama Nusantara is a manufacturer of refillable bottled water in the Regency, South Kalimantan. The marketing area for the time being is only 2 regions, namely in Tabalong district and Balangan district. The company also has a message sales method between or delivery orders, making it easier for customers to get the desired order. At present PT Kalimantan Jaya Utama Nusantara strives to develop its business to increase product sales.

Based on interviews with PT Kalimantan Jaya Utama Nusantara, information on sales for the period of 2016, 2017, 2018 has been obtained as shown in the following data; sales in 2016 amounted to Rp 203,864,000.00, sales in 2017 amounted to Rp 199,932,000.00, and sales in 2018 amounted to Rp 198,624,000.00. From these data, there was a decline in sales of $1.08 \%$ in 3 years. This is because the company is unable to develop its business and the lack of information produced.

Since the establishment of PT Kalimantan Jaya Utama Nusantara in 2007 until now, the company only presents sales reports in the form of simple tables containing customer booking transactions and cannot yet find out information about how many customers develop. This made PT Kalimantan Jaya Utama Nusantara confused when there were more customer orders than usual, and these customers were not served as a whole. So that customer development information is needed by PT Kalimantan Jaya Utama Nusantara. As a benchmark for determining the success of a company in business, a sales target is needed for PT Kalimantan Jaya Utama Nusantara. But now PT Kalimantan Jaya Utama Nusantara has not had a procedure for establishing and monitoring the achievement of sales targets so that the company does not have clarity about how many sales it wants to achieve. This makes it difficult for PT Kalimantan Jaya Utama Nusantara to be motivated, reports produced are not informative, and tend to make sales less than optimal.

Gallon drinking water is an item that has a live time period where when it has passed that period the gallon must be stopped operating and a new gallon must be replaced to reduce the risk of gallon fragility. Therefore the company needs gallon history information because currently PT Kalimantan Jaya Utama Nusantara still has difficulty in identifying gallons that have passed the live time period so customers often feel uncomfortable about the gallons received.

According to Ichwan (2011), Technology in sales has an important role to improve the quality of business processes of companies or business entities. If it is not supported by technologies such as desktop and web-based technology, it is possible that the sales will not run optimally. According Suhayati and Anggadini (2009: 225), "Sales Information System is an information system that organizes a series of procedures and methods designed to produce, analyze, disseminate and obtain information to support decision making regarding sales".

To obtain information in overcoming customer development problems, it requires proper reporting in the development of customers to help the company in analyzing customer development in each region and each 
period. To overcome the problems in setting and achieving targets, it is necessary to report the determination and achievement of the target company to assist in analyzing the achievement of sales targets set by the company. To overcome the problem of identifying gallons that have passed the live time period, information on recording the right data from the history of the gallon is needed to analyze whether the gallon is still feasible to rent or not.

At PT Kalimantan Jaya Utama Nusantara, the sales business process only uses a few steps from the sales cycle, namely responding to requests for information from customers, recording orders, checking availability, sending goods to customers, collecting payments, and preparing reports. With the information system that will be created can help companies analyze information, see opportunities, evaluate sales, and make the right decisions to increase sales and ordering of drinking water in the company.

In order to make the information system well done, it is necessary to analyze and design an information system for drinking water sales at PT Kalimantan Jaya Utama Nusantara.

\section{Method}

In carrying out the analysis and design of this sales information system, several research methods are used as follows:

1. Identifying Problems, Opportunities, and Objectives.

2. Literature Study

Based on the existing case studies obtained several related theories, namely:

a. System

According to McLeod (2001), the system is a set of interrelated elements so as to form a unified and integrated entity.

b. Information

According to Hartono (2005: 8), "Information is data that has been processed into a form that is more useful and more meaningful for those who receive it". This cycle can be seen in Figure

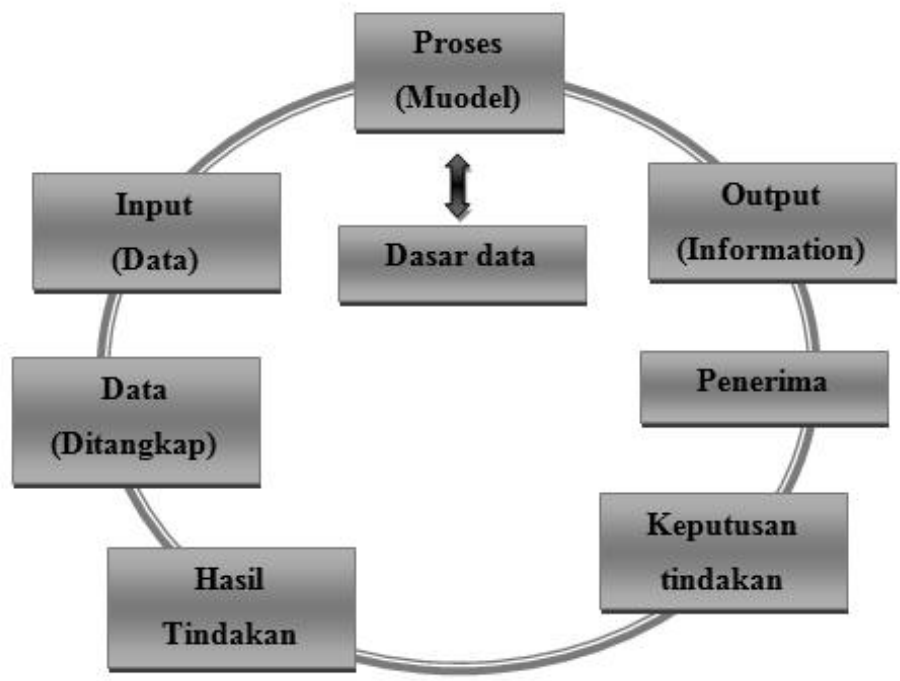

Figure 1. Information Cycle (Hartono, 2005)

c. Information System

According to Hartono (2005), Information Systems is a system within an organization that brings together the needs of daily transaction processing, supports operations, is managerial and strategic activities of an organization and provides certain outside parties with the necessary reports.

d. Sales

The sales cycle for companies according to Rama and Jones (2006: 18) includes the following activities:

i. Respond to requests for information from customers. 
ii. Develop agreements with customers to provide goods or services in the future (recording orders).

iii. Check inventory availability

iv. Providing services or sending goods to customers

v. Bill customers

vi. Collect customer payments

vii. Deposit money to the bank

viii. Prepare report

e. Sales Information System

According Suhayati and Anggadini (2009: 225), "Sales Information System is an information system that organizes a series of procedures and methods designed to produce, analyze, disseminate and obtain information to support decision making regarding sales".

f. System Analysis and Design

According to Hartono (2005: 129), "System analysis can be defined as the decomposition of a complete information system into its component parts with the intention of identifying and evaluating problems, opportunities, constraints that occur and needs expected so that improvements can be proposed ".

g. System Development Lifecycle

System Development Life Cycle (SHPS) or in a foreign language called the System Development Life Cycle (SDLC) is an approach, of course, through several stages to analyze and design a system that has been well developed through the use of specific analyzer and user activity cycles (Kendall and Kendall , 2003).

\section{h. Likert Scale}

Type of Likert scale measurement according to Sugiyono (2009: 134), Likert scale is a type of scale used to measure attitudes, opinions, and perceptions of a person or group of people about ongoing social events or symptoms. Likert scale is used with a weight value containing 1 to 5 .

3. Field Study

4. Business Process Analysis

5. Analyzing System Needs

Based on the analysis of business processes, a sales information system can be designed such as a block diagram in Figure 2.

Figure 2. Block Sales Information System Analysis and Design Diagram at PT Kalimantan Jaya Utama Nusantara Input Customer Data Output Process Gallon Sales Data Data Sales Target Data Analyze Achievement of Sales Target Analyzing Customer Development Analyzing Gallon Stock Analyzing Live Time Gallon Recording Customer Registration via SMS Recording Ordering Customers via SMS Problem Analysis Performing Analysis of Operational Analysis Analysis of Data Needs Analysis of Availability Capacity Analysis Performance Analysis Reliability Analysis Security Analysis Interview Results Results of Observation Study Literature Performs DAPL Document Design (Software Design and Architecture) Results of SKPL Document Analysis (Software Requirements Analysis ).

6. Designing a Recommended System

\section{Results and Discussion}

The final result of the Analysis and Design of the System is a document of analysis and design of information systems for drinking water sales at PT Kalimantan Jaya Utama Nusantara which contains:

\section{Software Requirement}

Software requirements are used to determine user needs in the use of information systems, which consist of:

a. Requirement Elicitation

1. User Identification:

This Information System has three users, namely the Shipping Staff, Listing Staff, and the owner

2. Identification of Functions:

- Current Functions

- New Functions 
- Table 1. Identification of Functions

\begin{tabular}{|c|c|}
\hline Current Functions & New Functions \\
\hline & $\begin{array}{l}\text { 2. Monitor function } \\
\text { Live time for Galom } \\
\text { 3. Checking function } \\
\text { Availability of Gallons }\end{array}$ \\
\hline $\begin{array}{l}\text { Recording Staff: } \\
\text { 1. Record customer orders } \\
\text { 2. Make proof of delivery } \\
\text { 3. Recap customer payments } \\
\text { 4. Make a sales report }\end{array}$ & $\begin{array}{l}\text { 1. Function of Managing Customer Data } \\
\text { 2. Function Manage and monitor Customer Order } \\
\text { Transactions } \\
\text { 3. Function of Inputting Customer Service } \\
\text { 4. Function Print order proof and proof of shipment }\end{array}$ \\
\hline $\begin{array}{l}\text { Admin: } \\
\text { (No admin yet) }\end{array}$ & $\begin{array}{l}\text { 1. Function of Managing Employee Data and Employee } \\
\text { Tasks } \\
\text { 2. Function of Managing Regional Marketing Data } \\
\text { 3. Function of Managing Promo Data } \\
\text { 4. Function of Managing Product Data } \\
\text { 5. Function of Managing Target Indicators and Sales } \\
\text { Targets }\end{array}$ \\
\hline $\begin{array}{l}\text { Owner: } \\
\text { 1. Establish selling prices and promos } \\
\text { 2. See all sales information } \\
\text { 3.Ensure the return of sales reports and money } \\
\text { received. }\end{array}$ & $\begin{array}{l}\text { 1. Function of Analyzing Sales Targets } \\
\text { 2. Function of Analyzing Customer Development } \\
\text { 3. Function of Analyzing Gallon Stock Needs } \\
\text { 4. Function of Analyzing Live time of Gallons } \\
\text { 5. Function of Making Reports }\end{array}$ \\
\hline
\end{tabular}

\section{b. Requirement Spesification}

Requirements for software specifications can be divided into functional requirements and non-functional requirements.

1. Functional requirements

Functional requirements are functions that will be used in information systems.

2. Non-functional needs

Functional requirements are needs that are not directly related to certain features. Non-functional needs limit the functional requirements.

\section{Software Design}

Software design is all processes in defining the architecture, components, interfaces and characteristics of a system and / or other components and the results of the process. Software design analysis and design of information systems for selling drinking water at PT Kalimantan Jaya Utama Nusantara consists of: 


\section{Tiered Diagram}

The hierarchical diagram (Hierarchy Chart) is used to describe the entire process of the level and group of processes involved. In this case study, the design consists of the process of managing data, making sales, and making reports that each sub-process is used as a guide in designing Data Flow Diagrams.

\section{Data Flow Diagram (DFD) Context Level}

Context Diagram of sales information system at PT Kalimantan Jaya Utama Nusantara can be four external entities, namely delivery staff, recording staff, owners, and customers. Besides that it has sub-processes:

a. Level 0 consists of Managing Data, Making Sales, and Making Reports.

b. Level 1 Managing Data consists of Managing Customer Data, Managing Employee Data, Managing Product Data, Managing Gallon Data, Managing Regional Data, Managing Data Promos, and Managing Sales Target Data

c. Level 1 Makes Sales consisting of Making Order, Registering Gallon Circulation, Making Payment Records, and Conducting Analysis.

d. Level 1 Creating Reports consists of Selecting Reports, Determining Report Periods, Printing Reports

e. Level 2 Sales consists of Checking Customer Data, Saving Orders, and Printing Evidence

f. Level 2 Registering Payments consists of Checking Customer Debt and Saving Payment Transactions

g. Level 2 Conducts an Analysis consisting of Conducting an Analysis of the Achievement of Sales Targets, Conducting Analysis of Customer Development, Analyzing Stock Stock Requirements, and Analyzing Live Time Gallons.

\section{Entity Relationship Diagram (ERD)}

ERD shows the overall structure of data requirements from system users consisting of:

\section{a. Conceptual Data Model (CDM)}

The CDM design of sales information systems at PT Kalimantan Jaya Utama Nusantara consists of 17 tables namely Inbox tables, Sent Items, Outboxes, Multipart Outboxes, Regions, Customers, Employees, Logs, Targets, Grades, Tasks of Employees, Products, Promos, Gallons, Orders, Payments, and Sales which can be seen in Figure 3.

\section{b. Physical Data Model (PDM)}

PDM design sales information system in PT Kalimantan Jaya Utama Nusantara consists of 10 tables, Input_Field table, location_delivery, type_delivery, id_post, type_purchase, price_bright, type_bright, date_delivery, officer_db, id_buyer which is the result of generating Gallon table and Sales table which can be seen in Figure 4. 


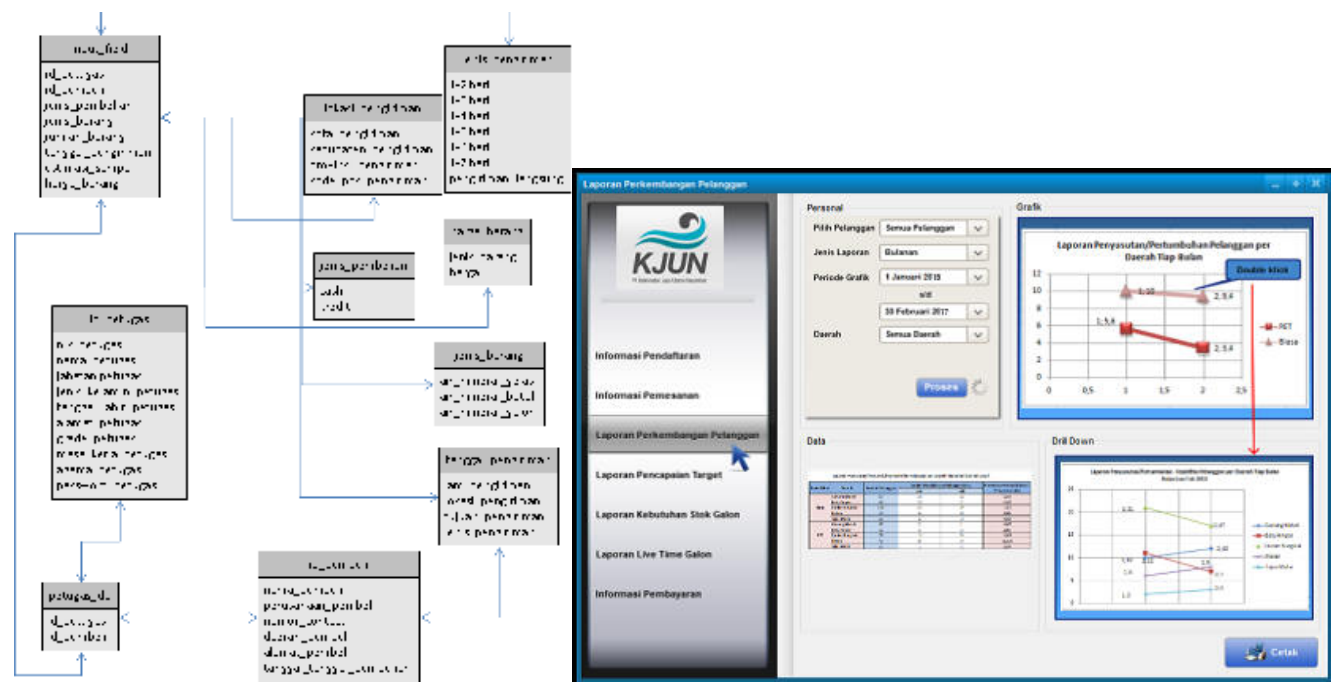

Figure 2. Design Display of Reporting Customer Development Menu

\section{Interface Reporting Menu Design}

a. Reporting Customer Development Analysis

This customer development report is a report of the results of an increase or decrease in the number of customers who register every certain period.

b. Reporting Analysis of Achievement of Sales Targets

This sales target achievement report is the result of a comparison of sales targets, and total sales for certain periods based on applicable sales target indicators.

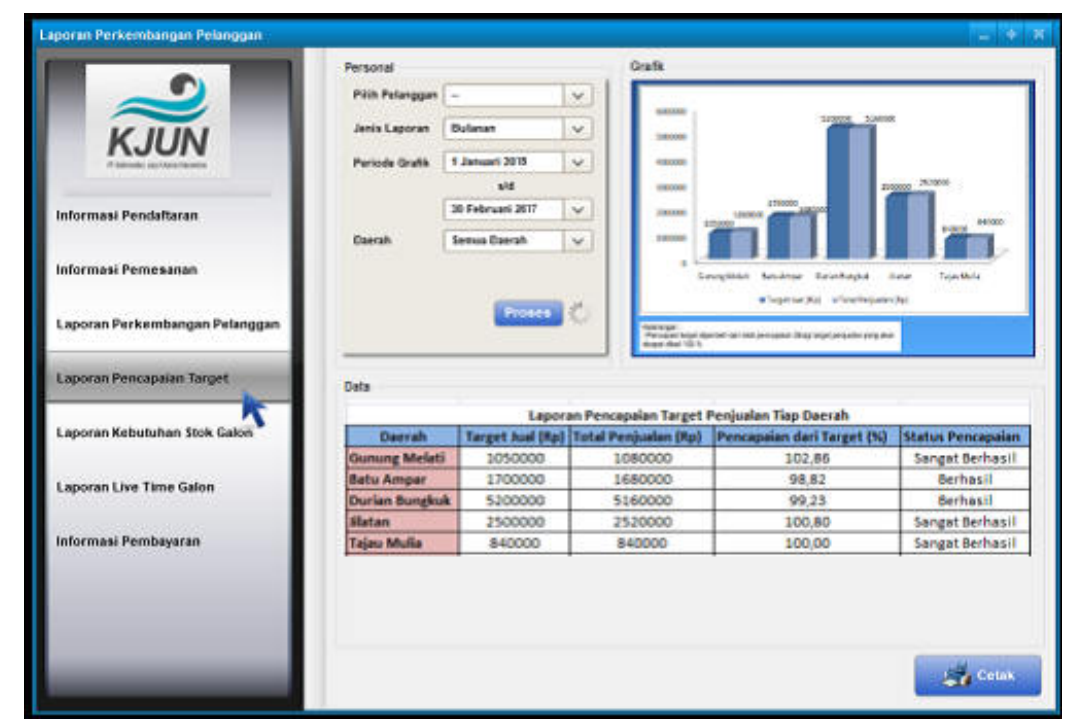

Figure 3. Display of Reporting Customer

\section{c. Reporting Gallon Stock Needs Analysis}

The report on the need for gallon stock is obtained from a comparison of the calculation of the gallon stock requirement for customer development. So that it can be known whether the available gallons can meet the needs 
of the next customer.

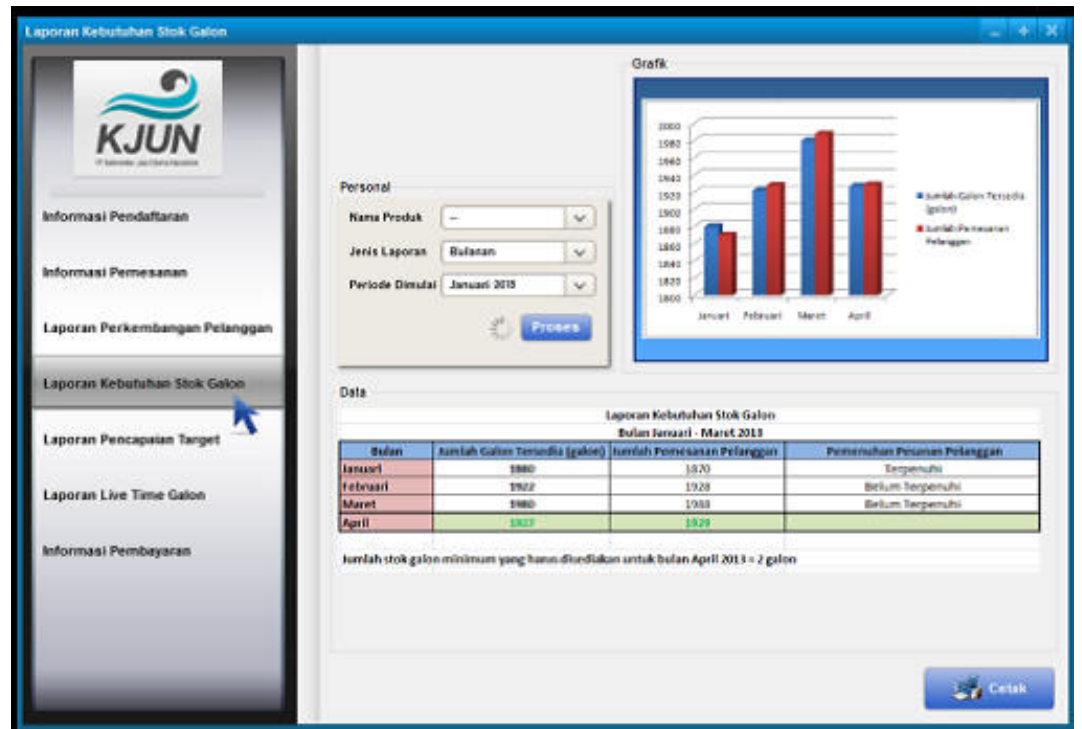

Figure 7. Menu Display Design Reporting Gallon Stock Requirements

\section{Conclusion}

From the analysis and design of the sales information system at PT Kalimantan Jaya Utama Nusantara, a conclusion was obtained that the draft information system for drinking water sales at PT Kalimantan Jaya Utama Nusantara was able to produce a sales information system design that could be used by system developers to meet PT Kalimantan Jaya's information needs Utama Nusantara which includes designing registration and ordering customers via SMS, recording history and gallon lifetime, and making sales reports.

\section{References}

Hartono, J. (2005), “Analisis dan Desain Sistem Informasi. Yogjakarta”.

ANDI Ichwan, M. Y. (2011), “Peran dan Dampak Teknologi di Bidang Pemasaran”. Malang: Universitas Negeri Malang.

Kendall, K.E. dan Kendall, J.E. (2003), “Analisis dan Perancangan Sistem”. (B. M. Thamir Abdul Hafedh A1Hamdany.

McLeod, J. R. (2001), ” Sistem Informasi (7 ed.). Jakarta: Prenhallindo Rama, Dasaratha V dan Jones, Frederick L. 2006.

Accounting Information System (1 ed.). Cannada: Thomson South-Western Sugiyono. (2009). "Metode Penelitian Kuantitatif, Kualitatif dan R\&D”. Bandung: Alfabeta. Zulkifli Ahmad (2017), "Modelling Sistem Informasi Penjualan dan Pembelian Obat Pada Apotek Rindani Sejahtera Pekanbaru”, Pekanbaru - Riau.

Windi Luki Lestari (2010), “Aplikasi Sistem Informasi Pembelian dan Penjualan Pada Toko Citra Computer Cilacap". Cilacap.

Nugroho Adi (2010), “Rekayasa Perangkat Lunak Berorientasi Objek dengan Metode USDP”, Yogyakarta.

Egie Imandha (2016), “ Sistem Informasi Pembelian Penjualan Dilengkapi Decission Support System Untuk Penentuan Supplier”, Bandung. 